\title{
Correction to: What shapes farmers' perception of climate change? Evidence from southern Brazil
}

\author{
Cristian Rogério Foguesatto $^{1}$ (D) . João Armando Dessimon Machado ${ }^{1}$
}

Published online: 19 January 2021

(c) Springer Nature B.V. 2021

\section{Correction to: Environment, Development and Sustainability https://doi.org/10.1007/s10668-020-00634-z}

Unfortunately, there is a word error in the title of the original publication of the paper. We apologize for our mistake.

The correct title is: What shapes farmers' perception of climate change? Evidence from southern Brazil

Publisher's Note Springer Nature remains neutral with regard to jurisdictional claims in published maps and institutional affiliations.

The original article can be found online at https://doi.org/10.1007/s10668-020-00634-z.

Cristian Rogério Foguesatto

cristian_rogeriof@hotmail.com

1 Centro de Estudos e Pesquisas em Agronegócios, Universidade Federal do Rio Grande do Sul, Porto Alegre, Brazil 